\title{
INDEX TO VOLUME 4
}

Bereznaya, I. Y. \& Granovskaya, R. M. Robot vision as a problem of picture analysis optimization, 189-192

Busby, H. R. See Schiebel, Busby, \& Waldron

Camarinha-Matos, L. M. See Steiger-Carçao \& Camarinha-Matos

Coudurier, J. F. Flexible production organization of workpiece movement, 33-36

Formal'sky, A. M. See Lensky, Lizunov, Formal'sky \& Shneider

Gascoigne, J. D. See Weston, Sumpter \& Gascoigne

Granovskaya, R. M. See Bereznaya \& Granovskaya

Havlik, S., A three axis tactile sensor-probe for robotic use, 229-235

Ho, C. Y. \& Jen, S. Differential relationship of kinematic model and speed control strategies for a computer-controlled robot manipulator, 155-161

Hunt, K. H., Special configurations of robot-arms via screw theory, 171-179

Huston, R. L. \& King, T. P. Dynamics of redundant robots-inverse solutions, 263-267

lyengar, S. S., Jorgensen, C. C., Rao, S. V. N. \& Weisbin, C. R. Robot navigation algorithms using learned spacial graphs, 93-100

Jakšić, N. See Potkonjak \& Jakšić

Jen, S. See Ho \& Jen

Jorgensen, C. C. See Iyengar, Jorgensen, Rao \& Weisbin

Jumarie, G. On the use of time-varying inertia links to increase the versatility of manipulations, 101-105

Karnik, A. M. \& Sinha, N. K. Adaptive control of an industrial robot, 243-246

King, T. P. See Huston \& King

Kirćanski, N. See Vukobratović \& Kirćanski

Koenig, E. C. Some principles for robotics based on general automata, 43-46

Krustev, E. \& Lilov, L. Kinematic path control of robot arms, 107-116

Lensky, A. V., Lizunov, A. B., Formal'sky, A. M. \& Shneider, A. Yu. Manipulator motion along a constraint, 247-253

Lilov, L. See Krustev \& Lilov

Lirov, Y. On synchronized proportional motion of multi-robot systems with stepper motors and shared controller, 151-154

Lizunov, A. B. See Lensky, Lizunov, Formal'sky \& Shneider

Meghdari, A. See Shahinpoor \& Meghdari

Middleditch, A. E. See Stacey \& Middleditch

Mohri, A. See Ozaki \& Mohri

Nevill, G. E. See Patterson \& Nevill

Owen, T. Robotics: the strategic issues, 117-122

Ozaki, H. \& Mohri, A. Planning of collision-free movements of a manipulator with dynamic constraints, $163-169$

Patterson, R. W. \& Nevill, G. E. The induced vibration touch sensor-a new dynamic touch sensing concept, 27-31

Potkonjak, V. \& Jaǩjić, N. Contribution to a computer-aided choice of D.C. motors for manipulation robots, $37-41$

Rao, S. V. N. See Iyengar, Jorgenson, Rao \& Weisbin

Schiebel, E. N., Busby, H. R. \& Waldron, K. J. Design of a mechanical proximity sensor, 221-227

Senker, P. Automation and Maintenance Training, 47-50 
Shahinpoor, M. \& Meghdari, A. Combined flexural-joint stiffness matrix and the elastic deformation of a servo-controlled two-link robot manipulator, 237-242

Shneider, A. Yu. See Lensky, Lizunov, Formal'sky \& Shneider

Sinha, N. K. See Karnik \& Sinha

Stacey, T. W. \& Middleditch, A. E. The geometry of machining for computer-aided manufacture, 83-91

Steiger-Cargao, A. \& Camarinha-Matos, L. M. CONCURRENT PASCAL as a robot level language-a suggestion, 269-272

Sumpter, C. M. See Weston, Sumpter \& Gascoigne

Vukobratović, M. \& Kirćanski, N. Numerical complexity of decentralized dynamic control laws for manipulator systems, 255-262

Waldron, K. J. See Schiebel, Busby \& Waldron

Warszawski, A. Robots in the contruction industry, 181-188

Weisbin, C. R. See Iyengar, Jorgensen, Rao \& Weisbin

Weston, R. H., Sumpter, C. M. \& Gascoigne, J. D. Distributed manufacturing systems, 15-26

Wiltshire, J. Manpower and training problems in the U.K., 51-53 


\section{INDEX OF BOOKS REVIEWED IN VOLUME 4}

The name of the reviewer of the book is given in parentheses

Appelt, D. E. Planning English Sentences, (A. M. ANDrew), 210-211.

Baser, T. \& Pao, L. F. (Eds.) Dynamic Modelling and Control of National Economics 1983. (Nicholas J. Rau), 131.

Batchelor, B. G., Hill, D. A. \& Hodgson, D. C. (Eds.) Automated Visual Inspection. (Peter B. SCOTT), 131-132.

Beni, G. \& Hackwood, S. (Eds.) Recent advances in Robotics (Peter B. ScotT), 61-62.

Blume, C. \& Jakob, W. PasRo: Pascal for Robotics, (A. M. Andrew), 284.

Bonnet, A. Artificial Intelligence: Promise and Performance, (A. M. Andrew), 284.

Bonney, M. C. \& Yong, Y. F. (Eds.) 'International Trends in Manufacturing Technology' Series IV-Robot Safety, (PETER B. SCOTT), 209.

Cardoza, A. \& Vlk, S. J. Robotics, (Peter B. ScotT), 208.

Dowty, D. R., Karttunen, L. \& Zwicky, A. M. (Eds.) Natural Language Parsing: Psychological, computational, and theoretical perspectives. (A. M. ANDREw), 211.

Duce, D. A. (Ed.) Distributed Computing Systems Program. (IAIN David CRaIG), 136.

Ebdon, D. Statistics in Geography, (P. EsRom), 210.

Electronic Market Data Book 1985, (J. EsROM), 284.

Engelberger, J. F. Robotics in Practice, (W. K. TAYLOR), 286.

Flurscheim, C. H. (Ed.) Industrial Design in Engineering: A Marriage of Techniques. (D. A. BRADLEY), 133,

Forsyth, R. \& Naylor, C. The Hitch-Hiker's Guide to Artificial Intelligence, (A. M. ANDREw), 207.

Hanafusa, H. \& Inoue, H. (Eds.) Proceedings of the Second International Symposium on Robotics Research, (PETER B. SCOTT), 208-209.

Hillis, w. D. The Connection Machine, (A. M. ANDREw), 284.

Holland, R. C. Illustrated Dictionary of Microelectronics and Microcomputers. (J. EsROM), 133.

Holmes, J. N. (Ed.) Speech Technology: Proceedings of the First International Conference. (A. M. ANDREW), 135.

Holmes, W. M. (Ed.) Artificial Intelligence and Simulation, (A. M. ANDREw), 283.

Industrial Robots, Second Edition, (J. EsRom), 283.

Information Technology Research and Development: Critical Trends and Issues, (A. M. ANDREW), 285-286.

Lindkuist, R. G. T. Handbook of Materials Handling. (PETER B. SCOTT), 132-133.

Martin, H. L. \& Kuban, D. P. (Eds.) Teleoperator Robotics in Hostile Environments, (PETER B. SCOTT), 287.

McKeown, K. R. Text Generation, (A. M. ANDREw), 210-211.

Morecki, A., Ekiel, J. \& Fidelus, K. Cybernetic Systems of Limb Movements in Man, Animals and Robots. (Peter B. Scott), 63.

Morgan, C. Robots: Planning and Implementation. (Peter B. SCOTT), 62.

Moto-Oka, T. \& Kitsuregawa, M. The Fifth Generation Computer: The Japanese Challenge, (A. M. ANDREw), 207-208.

Muller, Dr-Ing Thomas, Automated Guided Vehicles. (Peter B. ScotT), 132-133.

Narayanan, A. \& Sharkey, N. E. An Introduction to LISP, (P. Esrom), 210.

Nof, S. Y. (Ed.) Handbook of Industrial Robotics, (J. EsROM), 284-285.

Owen, A. E. Flexible Assembly Systems. (Peter B. ScotT), 132.

Pagels, H. R. (Ed.) Computer Culture. (Constantin Negoita), 135-136.

Proceedings of the International Symposium on Automotive Technology and Automation, ISATA '84. (T. J. VICKERSTAFF), 61.

Proceedings of the 5th International Conference on Robot Vision and Sensory Controls, (PETER B. SCOTT), 287. 
Rathmill, K. (Ed.) 'International Trends in Manufacturing Technology' Series III-Robotic Assembly, (Peter B. Scotr), 209.

Robotics, CAD/CAM Market Place 1985. (J. EsRom), 134.

Scott, P. The World Yearbook of Robotics Research and Development, second edition, (P. ESROM), 286-287.

Shirai, Y. \& Tsujii, Jun-ichi. Artificial Intelligence: Concepts, Techniques and Applications. (A. M. Andrew), 134.

Smith, D. N. \& Heytler, Jr, P. Industrial Robots, forecasts and trends, a second editon Delphi study, (J. EsRoM), 283.

Systems Security-The Key to Computer Integrity. (IAIN David Craig), 136.

The Australian Robot Marketplace-A Comprehensive Independent Guide to Robots in Australia, (Peter B. Scott), 209.

Tulkoff, J. (Ed.) Computer Aided Process Planning, (Peter B. SCOTt), 287.

Vukobratović, M. \& Stokić, D. Scientific Fundamentals of Robotics 2. Control of Maniputated Robots. (B. L. DaviEs), 134-135.

Watkins, M. M. Research Centers Directory, (J. EsRom), 209-210. 


\section{At The Moving Frontier}

New

Machine Interpretation of Line Drawings

Kokichi Sugihara

This book solves a long-standing problem in computer vision, the interpretation of line drawings and, in doing so answers many of the concerns raised by this problem, particularly with regard to errors in the placement of lines and vertices in the images.

Artificial Intelligence Series

$\$ 30.00$ illustrated

New

Kinematics of Robot Manipulators edited by J.M. McCarthy

The theory and methodology of design of general-purpose machines that may be controlled by a computer to perform all the tasks of a set of special-purpose machines is the focus of modern machine design research. These seventeen contributions chronicle recent activity in the analysis and design of robot manipulators that are the prototype of these general-purpose machines. They focus particularly on kinematics, the geometry of rigid-body motion, which is an integral part of machine design theory.

$\$ 20.00$ softcover

\section{Robot Vision}

\section{Berthold Klaus Paul Horn}

Horn presents a coherent approach to the fast moving field of machine vision. Using a consistent notation based on a detailed understanding of the image formation process, his book covers even the most recent research and will prove useful to professionals working in the fields of machine vision, image processing, and pattern recognition.

$\$ 39.50$ 


\section{KYBERNETES \\ International Journal of Cybernetics and Systems \\ (a quarterly)}

EDITOR: Dr J. Rose

ASSISTANT EDITORS:

Professors

F. H. George (UK), T. C. Helvey (USA),

E. Nicolau (Romania) and Wu Xuemou (China)

ADVISORY BOARD:

Professors

Chen Hanfu (China), S. Dillon Ripley (USA),

U. S. von Euler (Nobel Laureate, Sweden),

M. Manescu (Romania) and E. Wolff (France)

There are also 15 section editors from 8 countries and 21 members of the Editorial Board from 11 countries

This journal is concerned with the interdisciplinary study of cybernetics and systems in the widest sense. Among the extensive range of topics covered are the following: Artificial Intelligence, Automation, Cybernetic Modelling, Computer Simulation, Biocybernetics, Economic and Social Systems, Nature and Validation of General Systems, Ecosystems, Adaptive Systems, Philosophy of Cybernetics, the Interrelation between Cybernetics and other Sciences.

Kybernetes, now in its fourteenth year of publication, aims to endow cybernetics and general systems with an authoritative voice of its own and to establish a competent forum for the exchange of knowledge and information in relevant fields. One of the primary objectives of this publication is to weed out pseudo-cybernetics claims and to base cybernetics on a sound foundation; hence, highly speculative papers that lie on the fringe of cybernetics and systems sciences will not be published. The journal contains only original papers; it is the official publication of the World Organisation of General Systems and Cybernetics.

Enquiries and orders to:

THALES PUBLICATIONS (W.O.) LTD.

5 Margate Road

ST. ANNES-On-SEA

Lancs. FY8 3EG ENGLAND

(Tel. 0253 725114)

SUBSCRIPTION RATES PER VOLUME OF FOUR QUARTERLY ISSUES (includes air mail delivery to countries outside Europe):

Great Britain ... £50.00

Outside Great Britain ... (U.S.)\$120.00

For Advertising Rates and Back Issues enquire at Thales Publications (W.O.) Ltd, as above.

A PRESTIGE PUBLICATION, INDISPENSABLE TO

YOUR ORGANISATION AND TO YOU

NOW IN ITS FIFTEENTH YEAR 


\section{Notes for Contributors}

1. Manuscripts should preferably be written in English, but papers in French and German will also be accepted. All manuscripts will be referred to acknowledged experts in the subject. Only those receiving favourable recommendations from the referees will be accepted for publication. Manuscripts may be sent to any Board member, any Deputy Editor or the Editor.

2. Typescripts should be double spaced, on one side of good grade paper, allowing a reasonable left-hand margin. An original and two copies should be submitted with the author's full postal address, position and affiliations.

3. A short abstract of about 80 words should precede the main text. List of symbols: A typewritten list of any special symbols should be submitted with the manuscript. The list should not define the symbols mathematically, but should serve to identify them typographically. The list will not appear in print, but is essential to help the typesetter and to avoid costly correction in proof.

4. One copy of photographs, prints or transparencies of good quality and unmarked should be submitted. Where lines or lettering are to appear on the photograph, an additional print should be supplied appropriately marked. Each should have, lightly written on the back, the author's name, the figure number and an indication of which is the top of the picture.

5. One copy of each line diagram should be submitted at approximately twice final size and unlettered. Diagrams must be drawn in indian ink on plain white or transparent paper. A second copy should be supplied with lettering included. The author's name and the figure number should be written on this copy. Figures should be numbered consecutively, with arabic numerals, have descriptive captions, and be mentioned in the text. The correct position for each figure should be indicated in the margin of the manuscript.

6. Tables should be typewritten on separate sheets. Avoid, where possible, very wide tables. Number tables consecutively with roman numerals. Each should have a brief heading. Exceptionally lengthy tables may be summarized for publication with a note that copies of details can be obtained from the authors.

7. Equations: Wherever possible, mathematical equations should be typewritten, with subscripts and superscripts clearly indicated. The printer will set all mathematical symbols in italics unless otherwise indicated; symbols or letters to be set in roman (upright) type should be encircled in pencil, while bold letters should be shown by a wavy underline.

8. References: In the text, references are indicated by superior arabic numbers (without brackets), and should be confined to publish work that is directly pertinent. References should be listed at the end of the paper in numerical order. Authors' initials should precede their names; cited article titles should be quoted in full, enclosed in quotation marks; and abbreviations of journal names should follow the style of Chemical Abstracts or Physical Abstracts, and be underlined for italics: P.W. Anderson, "More is different" Science 177, 393 (1972) C.V. Negoita, Fuzzy Systems (Abacus Press, Tunbridge Wells, UK, 1980)

Citations such as 'personal communication', 'unpublished work', etc., are not acceptable as numbered references but can be included in parenthesis in the text. Do not use summaries as references.

9. Proofs: Page proofs will be sent to authors for correction, for return within 48 hours by airmail. Correction to proofs should be restricted to printers' errors only. Authors are entitled to 25 offprints of their article free of charge. Additional offprints may be purchased if they are ordered on the form sent with the proofs.

10. Manuscripts, whether accepted or rejected, will not be returned to the authors.

11. Submission of an article will be taken to imply that it has not been previously published and that it is not on offer to any other publisher. 


\section{CONTENTS}

Reports and Surveys (Automation in Italy, Education and Training, Flexible Manufacturing Systems, The Future with Information Technology, Integrated Office Automation, New Application for Automation, Robots in Nuclear Plants, Robots in the Supermarkets, Robots Worldwide, Software Reports, Warrior Robotic Project), B. H. Rudall (UK)

Resolved position control for two co-operating robot arms, Joonhong Lim and Dong H. Chyung (USA)

Special configuration of robot-arms via screw theory, K. H. Hunt (Australia)

On a human-arm-like mechanical manipulator, A. Hemami (Canada)

Dynamic direct subspaces for robot path planning, W. E. Red and K. H. Kim (USA)

A method for the generation and recording of industrial robots continuous trajectories, Robert Couderc, Georges Fannechère, Jean-François Poiraudeau and Serge Roux (France)

Extended kinematic path control of robot arms, Evgeny Krustev and Ljubomir Lilov (Bulgaria)

Separability of pairs of polygons through single translations, Jörg-Rüdiger Sack and Godfried T. Toussaint (Canada)

Special Feature

Conference Reports

Book Reviews

Announcements 